\title{
An Investigation of the Influence of Organizational Structure on Performance of Mobile Telephone Network Operators in Kenya
}

\author{
Grace Karemu, Musa Nyakora, Erastus Thoronjo, and Evans Mandere
}

\section{ABSTRACT}

The objective of the study was to investigate influence of organizational structure on performance of Mobile Telephone Network Operators in Kenya. Sub-variables used for the independent variable were teamwork organizational structure, learning organization structure and boundary-less structure. Performance of Mobile Telephone Operators in Kenya was analyzed in terms of profit margins and market share. Structural contingency theory was used to explain the relationship between organizational structures on performance. Mixed methodology was used in collecting and interpreting data. Primary data was gathered using selfguided semi-structured questionnaires and secondary data was obtained from published profit margins and percentages of market share obtained from the companies` reports. Study population was 6,167 which included all the employees in the Mobile Telephone Network Operators in Kenya and a total sample size of 361 employees was obtained but 258 questionnaires were filled and returned. Data analysis was done using descriptive statistics and inferential statistics. The study hypothesis was tested at $95 \%$ confidence interval and $0.05 \alpha$ level of significance. Study $\mathrm{H}_{0}$ stated that: Organizational structure does not positively influence performance of MTNOs in Kenya. Goodness of fit model demonstrated that organizational structure had a positive influence on organizations' performance of MTNOs accounting for $16.4 \%$ of the performance $(R$ squared $=0.164)$. The study concluded that there was a statistically significant influence of organizational structure on organization`s performance therefore rejecting the null hypothesis $\mathrm{H}_{0}$ at $\beta=$ 0.405 and $P=0.000$.

Keywords: MTNOs in Kenya, organization`s performance, organizational structure.
Submitted : June 03, 2021

Published : June 25, 2021

ISSN: $2507-1076$

DOI: 10.24018 /ejbmr.2021.6.3.908

Grace K. Karemu*

Mount Kenya University, Kenya.

(e-mail: gracekaremu2000@gmail.com) Musa Nyakora

Adventist University of Africa, Kenya.

(e-mail: nyakora.musa@yahoo.com)

Erastus M. Thoronjo

Mount Kenya University, Kenya.

(e-mail: ethoronjo@mku.ac.ke)

Evans Nyamboga Mandere

Mount Kenya University, Kenya.

(e-mail: enyamboga @mku.ac.ke)

* Corresponding Author

\section{BACKGROUND OF THE STUDY}

Today's global and competitive digital age requires organizations to work faster and achieve more with much less, hence, the demand for more agile, flexible organizational structures to increase efficiency and effectiveness to improve performance [1]. Appropriate organizational structures are therefore necessary for Mobile Telephone Network Operators (MTNOs) to achieve outstanding performance since they operate in a dynamic, digital, and competitive environment.

Appropriate organizational structure empowers employees, reduces centralized control giving employees autonomy over their job tasks and freedom to propose ways of carrying out tasks as they feel is appropriate, hence being able to hold themselves accountable and responsible for their own decisions, encouraging ownership culture for better performance [2]. The right organizational structures have been applied successfully by multinational companies like Apple, Samsung, and Huawei to convert use of new technology into new products which delight customers by giving them exciting experiences, resulting to companies' supremacy in the international market [3].

\section{A. Statement of the Problem}

According to Communications Authority of Kenya (CAK) sectorial reports, MTNOs in Kenya are faced with many performance challenges which include low to negative financial returns, drop in mobile money market share, decrease in mobile Short Messages (SMSs), reduced mobile voice traffic and drop in subscribers` market share: Airtel Kenya MTNO reported that it was bankrupt and could not meet its financial obligations and that the company was crumbling under over Sh55 billion short term debts whereas the current assets were about Kshs 10 billion reflecting a bad performance. The situation led to a Kshs 8 billion loss in 2016 and the MTNO had losses worth Sh59.3 billion by December 2017 (Airtel annual report, 2017).

Telkom Kenya in the last 10 years has faced problems which made profitability for the MTNO a mirage, and as a result the company has always reported low performance. The MTNO then decided to compete by lowering calling prices but suffered consequences due to lowering mobile call charges too low to lure subscribers, since the strategy plunged the company into further debts and losses (Telkom Kenya annual reports of 2015, $2016 \&$ 2017). Safaricom Ltd also has had its share of performance challenges over the years reporting a drop in its mobile money market share in 2014, a 
decline in subscribers market share in 2015, a loss in SMSs market share in 2016 and a decrease in local voice traffic in 2017 and 2018 (CAK reports of 2015, 2016, 2017, 2018). Effective organizational structures give employees autonomy, and this allow firms to respond faster to market changes to improve performance.

\section{B. Objective of the Study}

The objective of the study was to investigate influence of organizational structure on performance of MTNOs in Kenya.

\section{Research Hypothesis}

The study tested null hypothesis, which was stated as, $\mathrm{H}_{0}$ : Organizational structure does not positively influence performance of MTNOs in Kenya.

\section{LITERATURE REVIEW}

\section{A. Empirical Literature Review}

Organizational structure aligns units in organizations with missions, goals, and objectives, aiming to improve performance [1]. A new organizational structure may be activated by necessity for improvement of products or services to ensure that tasks, workflow, responsibility, and authority, reinforce the business vision [4]. Effective company structure aids transmission of information, efficiency, effectiveness and re-structuring and therefore outstanding organizational output and accomplishments are attributable to appropriate organizational structure and poor organizational productivity is a result of poor structure [5]. Today's global and competitive digital age requires organizations to work faster and achieve more with much less resources and time, hence, the demand for a more agile, flexible organizational structure to increase efficiency and effectiveness to improve performance [1]. Appropriate organizational structures are therefore necessary for MTNOs to achieve outstanding performance since they operate in a dynamic, digital, and competitive environment.

Appropriate organizational structure empowers employees, reduces centralized control giving employees autonomy over their job tasks and freedom to propose ways of carrying out tasks as they feel is appropriate, hence being able to hold themselves accountable and responsible for their own decisions, encouraging ownership culture for better performance [2], [6]. The right organizational structures have been applied successfully by multinational companies like Apple, Samsung, and Huawei to convert use of new technology into new products which delight customers by giving them exciting experiences, resulting to companies supremacy in the international market [7], [3].

Also, different researchers have published findings about impact of company`s structural design on performance: A researcher [8] studied organization`s structure to assess its effect on performance of commercial corporations in Kenya. Correlation and multiple linear regressions were used to establish relationship between studied variables. Organizational structure was defined using organizational size, structure formalization, structure centralization and structure complexity [8]. F-tests and t-tests were carried out and results indicated $\mathrm{F}$-test $=0.678$ with a significant value of $\mathrm{P}=0.000$, $\mathrm{t}$-tests for organizational size was 2.021 with a significance; $\mathrm{P}=0.045$, structure formalization had t-tests of 1.157 with a significant value of $\mathrm{P}=0.210$, structure complexity gave t-tests of 1.194 with a significant value of $\mathrm{P}=0.234$ and structure centralization gave $\mathrm{t}$-tests $=2.617$ with $\mathrm{P}=0.095$. All the four variables had strong positive relationships with performance. Conclusion by [8] was that organizational structure influenced financial performance of the corporations. However, since the researcher did not study MTNOs, this research analyzed influence of different structures on performance of MTNOs to fill the knowledge gap.

A research was done to find the connection in Bank's structure and performance in commercial Banks of Kenya and specific objective was to identify ways in which structure influenced Bank's performance [9]. Information was examined using SPSS and inferential statistics obtained helped in investigating cause and effect relationship to conclude findings. Linear regression was running, and ANOVA statistics table showed company structure was not a good predictor of performance since analysis model was significant at $\mathrm{P}=0.500$, (whereas the accepted level of significance was $\mathrm{P}=\leq 0.05$ ). In his study [9] found organizational structure did not determine performance since the level of the slope for organization structure was $\mathrm{t}=-0.683$. The researcher concluded that institutional structure did not determine performance. Since [9] did not research on MTNOs creating a knowledge gap, this study covered this gap by analyzing how Kenyan MTNOs structures influence performance.

Reference [10] studied effect of company`s structure on performance in banking system in Nigeria with main aim being to examine how structure affected performance, and specific objectives being to examine the extent to which a number of divisions or departments impacted profitability of the banks; and to determine extent to which number of bank branches impacted on profitability of the banks. Sample size was made up of five banks in Nigeria. Bank departments and number of bank branches were adopted as a measure of bank structure and performance was measured by profits after tax whereas number of board members was a moderator variable. It was found that departments had an optimistic effect on profitability of the banks (division coefficient $=0.041$, $\mathrm{P}=0.01<0.05, \mathrm{t}=2.519)$ [10].

The number of bank branches as a measure of structure also had a constructive control over profitability of banks in Nigeria (branches coefficient $=0.006, \mathrm{P}=0.0001<0.05, \mathrm{t}=$ -4.22). The negative $t$-value showed that as structure increased based on the number of bank branches; there was an increase in profit. The control variable, (number of members in the board had a positive impact on profitability of Nigerian banks (number of board members coefficient $=$ $0.525, \mathrm{P}=0.00<0.05$, $\mathrm{t}$-value $=20.062$ ).

\section{B. Theoretical Review: Structural Contingency Theory}

Authored by [11] the theory is of the view that the most appropriate organizational structure which can give an organization competitive advantages leading to an outstanding performance must be a structure which puts into consideration the contingencies faced by the organization. According to the theory, no specific structure befits all organizations at all times but rather, the management of any 
company must keep on changing the structure of their company to fit in well with the contingencies faced in the business environment, and therefore the organizational structure which supports above average performance is the one befitting contingencies to a greater degree.

Reference [12] postulated that structural contingency theory stresses the importance of proper fit between organizational design and the business environment for the organization to be effective to deliver high performance. The theory supports power of business environment contingencies to dictate changes in organizational structure to be able to respond promptly to upcoming contingencies. Firms which do not adapt structures favourable to the contingencies lose effectiveness and efficiency concerning how they meet customer needs and the way they deliver services [13].

A company that fails to match the dictates of the environment to the organizational structure, ends up being a laggard in the industry recording poor performances as a result of low productivity. Therefore, managers are restricted by changes in their business environment when modifying their company structures to increase performance. Companies operating in an environment with frequent technological advancements and changes in customer tastes and preferences like the Mobile Telephone Network Operators do not remain in a state of structural-environment fit for too long if they are to keep their performance high due to the changing markets and evolving technology and new strategies which keep on demanding new organizational structures to improve efficiencies and effectiveness. Proponents of the structural contingencies' theory argue that the adaption of structural contingency theory to achieve increased organization's performance is applicable to all organic organizations which are liable to keep on changing management structure to increase performance [13], [14].

\section{Conceptual Framework}

According to [15] a conceptual framework is a logical aid in form of a diagram that is utilized by a researcher to visually demonstrate comprehensively the interaction between indicators of the independent variables (which were studied) and the dependent variable. The scholar used the conceptual framework diagram to bring out the understanding about how predictor variables in the study connected with the response variable. It clarifies how the research objectives were formulated making it easier for the scholar to set out and expound the concepts within the problem of the study. Conceptual framework helps the researcher in recognizing and establishing viewpoints on the phenomenon to be investigated and it clearly defines the variables of the research topic and their relationships are shown by the use of arrows. In this study organizational structure was the independent variable measured in terms of teamwork organizational structure, learning organizational structure and boundaryless organizational structure while organizations' performance was the dependent variable measured in terms of profit margins and market share as presented in Fig. 1.

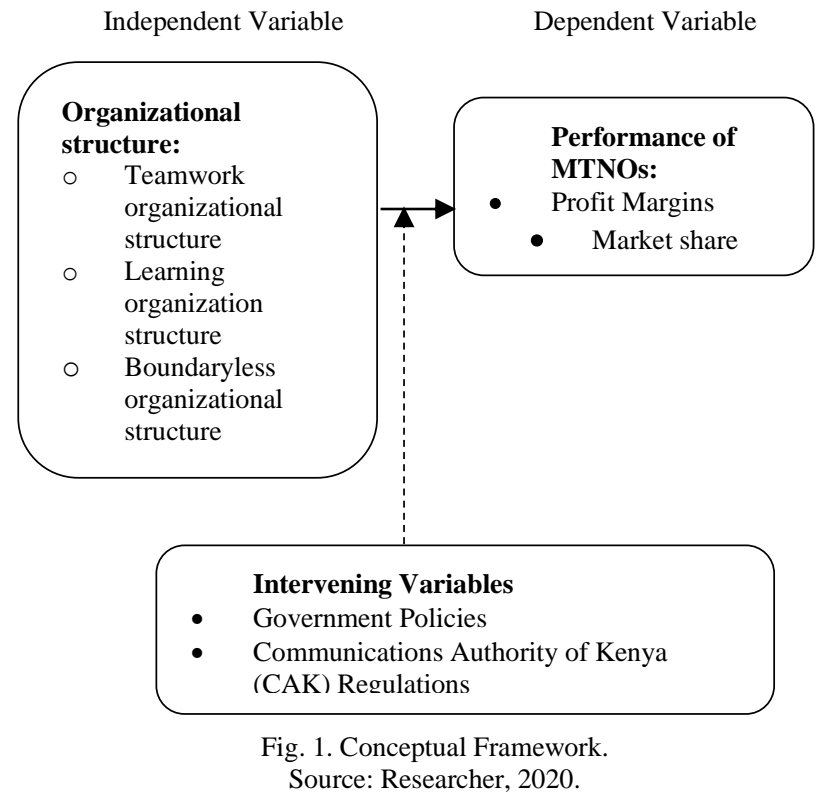

\section{RESEARCH METHODOLOGY}

Quantitative methodology was used where primary quantitative data was collected and analyzed on study measures of organizational structure (which was studied in terms of teamwork organizational structure, learning organization structure and boundary-less organizational structure) with regard to their influence on company's performance. Cross-sectional survey design helped this study in establishing relationships between study variables namely organizational structure and organization`s performance. According to [16], a cross-sectional research design helps in checking for significant associations between variables and in making generalizations concerning the target population. Cross-sectional research design has previously and successfully been used by researchers in business related studies including [8], [9].

\section{A. Target Population}

A target population includes all persons of a certain category to which a research is carried out. Thus, target population included all employees of the three MTNOs in Kenya. The researcher targeted all the employees of Safaricom MTNO, all employees of Airtel MTNO and all employees of Telkom Kenya MTNO. According to the company`s end of year report, (2017) employee count at Safaricom MTNO were 4,245. The second part of the population included all employees of Airtel in Kenya, who were 1,136 according to Airtel company report of December, 2018 and the third portion of the population comprised of 786 permanent employees at Telkom Kenya MTNO according to company`s annual report of 2018. The total population under study was therefore 6,167 employees from the three MTNOs as shown in Table I. 
TABLE I: TARGET POPULATION

\begin{tabular}{ccccc}
\multicolumn{5}{c}{ TABLE I: TARGET POPULATION } \\
\hline Department & Safaricom & Airtel & Telkom & T/P \\
\hline Finance & 94 & 33 & 23 & 150 \\
Mobile money & 262 & 76 & 53 & 391 \\
HRM & 96 & 21 & 17 & 134 \\
Procurement & 57 & 18 & 15 & 90 \\
Marketing & 316 & 134 & 94 & 544 \\
Customer care & 1282 & 423 & 287 & 1992 \\
Innovations & 93 & 46 & 36 & 175 \\
Engineering & 167 & 58 & 41 & 266 \\
Business unit & 64 & 27 & 18 & 109 \\
Strategy MGT & 253 & 32 & 23 & 308 \\
Sales MGT & 1052 & 141 & 96 & 1289 \\
Operations & 437 & 94 & 62 & 593 \\
Distribution & 72 & 33 & 21 & 126 \\
\hline Total & 4,245 & 1,136 & 786 & 6,167
\end{tabular}

HRM - Human Resource Management, MGT - Management and T/P-Total Population

Source: Safaricom Kenya, Airtel Kenya and Telkom Kenya records, (2019).

\section{B. Sampling Procedure, and Sample Size}

Since the total population of this study was 6,167 employees, the researcher obtained a sample size from Krejie and Morgan sample size table [17] which gave 361 employees. The researcher followed the principle of optimum allocation of sample size to strata and hence used proportionate stratification formula as was developed by [18] to ensure that sample sizes which were assigned each department were proportionate to the number of employees in the department as follows:

$$
n_{h}=\frac{N_{h} \times n}{N}
$$

where

$\mathrm{nh}=$ sample size for department, $\mathrm{h}$;

$\mathrm{Nh}=$ the population size for department, $\mathrm{h}$;

$\mathrm{N}=$ total population size;

$\mathrm{n}=$ total sample size.

Employees of MTNOs are heterogeneous having different knowledge and skills and working in different specialized departments and hence proportionate stratification formula was important to assign sample sizes to each stratum (departments). Table II below shows the sample size in each department as per employee population in the department as was calculated using the above proportionate stratification formula as was developed by [18]. Hence sample sizes for each MTNO where as follows: Safaricom had a sample size of 248 employees, Airtel 66, and Telkom 47 employees making a total of 361 employees sample size.

\begin{tabular}{ccccc}
\multicolumn{5}{c}{ TABLE II: SAMPLE SIZE } \\
\hline Department & SF & AT & TK & Total \\
\hline Finance & 6 & 2 & 1 & 9 \\
Mobile money & 15 & 4 & 3 & 22 \\
HRM & 6 & 1 & 1 & 8 \\
Procurement & 3 & 1 & 1 & 5 \\
Marketing & 18 & 8 & 6 & 32 \\
Customer care & 75 & 25 & 17 & 117 \\
Innovations & 5 & 3 & 2 & 10 \\
Engineering & 10 & 3 & 2 & 15 \\
Business unit & 4 & 1 & 1 & 6 \\
Strategy MGT & 15 & 2 & 1 & 18 \\
Sales MGT & 62 & 8 & 6 & 76 \\
Operations & 25 & 6 & 5 & 36 \\
Distribution & 4 & 2 & 1 & 7 \\
\hline Total & 248 & 66 & 47 & 361 \\
\hline
\end{tabular}

Source: Researcher, 2019.

Key: T/P-Total Population, SS-Sample Size.

$\mathrm{SF}$ - Safaricom, AT - Airtel, TK - Telkom

\section{Data Analysis Techniques}

Quantitative data was analyzed for hypothesis testing using quantitative techniques according to [19]. Descriptive statistics and inferential statistics were obtained using SPSS and interpreted: First the data was subjected to Kaiser Meyer Olkin and Bartlett's tests to verify appropriateness of the data set for correlation and regression analysis.

\section{IV.DATA ANALYSIS AND FINDINGS}

\section{A. Response Rate}

The researcher distributed 361 questionnaires for primary data collection from respondents but received back 258 filled questionnaires which presented a response rate of $71.496 \%$ as shown in Table III. A response rate of over $50 \%$ obtained during data collection for research is satisfactory, 60 percent is better and a reply rate of over $70 \%$ is the best [20]. Therefore, the $71.4 \%$ response rate which was achieved in this study was very good since it was over $70 \%$.

\begin{tabular}{llll}
\multicolumn{4}{c}{ TABLE III: QUESTIONNAIRE RESPONSE RATE } \\
\hline Job Category & QD & QR & RR in (\%) \\
\hline Executive & 18 & 13 & 72.222 \\
Manager & 19 & 13 & 68.421 \\
Supervisor & 23 & 17 & 73.913 \\
Other & 301 & 215 & 71.428 \\
\hline Total & 361 & 258 & 71.496 \\
Key: QD - Questionnaires Distributed, QR - Questionnaires Returned, RR \\
- Response Rate, Source: Primary data, 2020.
\end{tabular}

\section{B. Descriptive Statistics for Organizational Structure}

Descriptive figures were produced for all studied organizational structures (teamwork, learning and boundaryless organizational structures). Statements in the questionnaire were gauged by respondents using five-point Likert scale, ranging from strongly disagree to strongly agree and Table III showed resulting descriptive statistics.

The overall mean score of organizational structure was considerably high (3.6826) with the given statements having mean scores of between 3.4845 and 3.8760. Boundaryless organizational structures promote employee ownership of decisions, and this improves efficiencies had a mean of 3.6008; and team structures empower employees to build consensus and to gain ownership of decisions for better productivity got a mean of 3.6667. Teamwork structure has given employees sense of ownership of team roles improving job efforts and performance got a mean score of 3.6318 . Learning organizational structure allows discussions about the company`s vision leading to ownership for better performance got a mean of 3.7364; and learning structure enables participation in the innovation management for achievement of business goals efficiently had a mean of 3.7326 amongst other results. Boundaryless organizational structure gives employees new ways of solving problems boosting morale and creating ownership of job activities for increased effectiveness got a score of 3.6977, learning organizational structure gives employees knowledge which enable them to own actions for better performance scored 3.6628 , and team structures makes employees to own their job activities increasing effectiveness and productivity had a score of 3.8295 . 
TABLE IV: DESCRIPTIVE STATISTICS

\begin{tabular}{|c|c|c|c|}
\hline Statement given in the questionnaire & $\mathrm{N}$ & Mean & Std. Dev \\
\hline $\begin{array}{l}\text { Teamwork structure has given employees sense } \\
\text { of ownership of team roles improving job efforts } \\
\text { and performance }\end{array}$ & 258 & 3.6318 & 1.18358 \\
\hline $\begin{array}{l}\text { Team structures makes employees to own their } \\
\text { job activities increasing effectiveness and } \\
\text { productivity }\end{array}$ & 258 & 3.4845 & 1.28511 \\
\hline $\begin{array}{l}\text { Team structures give team members ability to } \\
\text { learn new skills giving them ownership of team } \\
\text { roles for increased efficiency }\end{array}$ & 258 & 3.6667 & 1.22448 \\
\hline $\begin{array}{l}\text { Team structures makes employees to take } \\
\text { ownership of their responsibilities to be self- } \\
\text { accountable for better outcomes }\end{array}$ & 258 & 3.8295 & 1.19091 \\
\hline $\begin{array}{l}\text { Team structures empower employees to build } \\
\text { consensus and to gain ownership of decisions for } \\
\text { better productivity. }\end{array}$ & 258 & 3.6279 & 1.25111 \\
\hline $\begin{array}{l}\text { Learning organization structures are built around } \\
\text { company values to instill ownership of goals for } \\
\text { more achievements }\end{array}$ & 258 & 3.7442 & 1.12128 \\
\hline $\begin{array}{l}\text { Learning organizational structure allows teams } \\
\text { to gain collective ownership of goals, hence } \\
\text { improving profits }\end{array}$ & 258 & 3.6047 & 1.21225 \\
\hline $\begin{array}{l}\text { Learning organizational structure allows } \\
\text { discussions about the company`s vision leading } \\
\text { to ownership for better performance }\end{array}$ & 258 & 3.7364 & 1.23515 \\
\hline $\begin{array}{l}\text { Learning structure enables participation in the } \\
\text { innovation management for achievement of } \\
\text { business goals efficiently }\end{array}$ & 258 & 3.7326 & 1.18115 \\
\hline $\begin{array}{l}\text { Learning organizational structure gives } \\
\text { employees knowledge which enable them to own } \\
\text { actions for better performance }\end{array}$ & 258 & 3.6628 & 1.21544 \\
\hline $\begin{array}{l}\text { Boundaryless organizational structures make } \\
\text { self-managing teams instill ownership of team } \\
\text { roles to increase effectiveness }\end{array}$ & 258 & 3.5504 & 1.19311 \\
\hline $\begin{array}{l}\text { Boundaryless organizational structures promote } \\
\text { employee ownership of decisions and this } \\
\text { improves efficiencies }\end{array}$ & 258 & 3.6008 & 1.24426 \\
\hline $\begin{array}{l}\text { Boundaryless organizational structure eliminates } \\
\text { unnecessary bureaucratic activities to achieve } \\
\text { goals effectively }\end{array}$ & 258 & 3.8760 & 1.11242 \\
\hline $\begin{array}{l}\text { Boundaryless organizational structure allows ad } \\
\text { hoc cross-functional teams to eliminate or } \\
\text { combine some activities and take ownership to } \\
\text { improve results }\end{array}$ & 258 & 3.7984 & 1.19258 \\
\hline $\begin{array}{l}\text { Boundaryless organizational structure gives } \\
\text { employees new ways of solving problems } \\
\text { boosting morale and creating ownership of job } \\
\text { activities for increased effectiveness }\end{array}$ & 258 & 3.6977 & 1.18094 \\
\hline Mean Score & & 3.6826 & \\
\hline
\end{tabular}

Factor analysis was used to authenticate the questionnaire by testing convergence, legitimacy, and building construct validity. KMO was used to analyze sample competences and Bartlett's test of Sphericity was done on data to regulate the appropriateness of using factor analysis. Varimax approach was used to extract smaller number of factors for each variable making it easier to interpret results. Principal Component Analysis approach was used to generate Eigen values for each component and using Eigen standards greater than one (1) or equivalent to one (1) fewer component were reserved for further analysis as recommended by [21].

Kaiser normalized rotated component matrix was generated where loadings with a magnitude greater than 0.7 were considered important in determining items of analysis which heavily loaded into each extracted component according to [22]. The measures of organizational structure (teamwork organizational structure, learning organizational structure and boundaryless organizational structure) were subjected to factor analysis in an effort to establish their suitability for factor extraction. The Kaiser-Meyer-Olkin (KMO) and Bartlett's Test of Sphericity was done to establish appropriateness of the data for factor analysis.

From Table V results, KMO of 0.632 suggests data sample was suited for factor analysis. Bartlett`s Test of Sphericity had $\mathrm{P}=0.000$ with an associated chi square of 256.742 . Responses from fifteen statements given in the questionnaire were analyzed. For data to be suitable for factor analysis it should have a KMO value greater than 0.5 and a Bartlett's Test of Sphericity with a $\mathrm{P}<0.05$.

\begin{tabular}{lcc}
\multicolumn{3}{c}{ TABLE V: KMO AND BARTLETT'S TESTS } \\
\hline KMO & \multicolumn{3}{c}{0.632} \\
& Approx. Chi- Square & 256.742 \\
df. & 14 \\
& \multicolumn{1}{c}{ Sign } & 0.000 \\
\cline { 2 - 2 } & \\
KMO - Kaiser Meyer Olkin. & \\
B/T- Bartlett's Test. & \\
Source: Primary Data, 2020.
\end{tabular}

Table VI below indicates total variance explained for organizational structure, giving eigenvalues and sums of squared loadings for each of the questionnaire items.

TABLE VI: TOTAL VARIANCE EXPLAINED

\begin{tabular}{ccccccc}
\hline & \multicolumn{5}{c}{ Initial Eigenvalues } & \multicolumn{3}{c}{ Sums of Squared Loadings } \\
\cline { 2 - 6 } Items & Total & Variance \% & $\begin{array}{c}\text { Cumulat } \\
\text { ive \% }\end{array}$ & Total & $\begin{array}{c}\text { \% of } \\
\text { Variance }\end{array}$ & Cumulative \% \\
\hline 1 & 2.60 & 12.02 & 12.02 & 1.80 & 12.01 & 12.01 \\
2 & 2.09 & 9.69 & 21.71 & 1.46 & 9.76 & 21.77 \\
3 & 2.06 & 9.54 & 31.25 & 1.44 & 9.63 & 31.41 \\
4 & 1.95 & 9.05 & 40.30 & 1.31 & 8.73 & 40.14 \\
5 & 1.79 & 8.30 & 48.60 & 1.12 & 7.52 & 47.67 \\
6 & .99 & 7.50 & 56.10 & & & \\
7 & .98 & 7.00 & 63.10 & & & \\
8 & .97 & 6.01 & 69.11 & & & \\
9 & .96 & 5.55 & 74.67 & & & \\
10 & .94 & 4.81 & 79.48 & & & \\
11 & .92 & 4.69 & 84.17 & & & \\
12 & .91 & 4.42 & 88.60 & & & \\
13 & .89 & 4.24 & 92.84 & & & \\
14 & .86 & 4.01 & 96.86 & & & \\
15 & .68 & 3.14 & 100.00 & & & \\
\hline
\end{tabular}

Extraction Method: Principal Component Analysis.

Source: Primary Data, 2020.

Kaiser Principle was used to maintain components with Eigenvalues $\geq 1$ and as a result, seven components were extracted as obtainable in Table VI. The study found 5 strong factors accounting for $48.60 \%$ of total variation in the organizational structure constructs. Factor one contributed $12.020 \%$ of the total variation, factor two contributed $9.69 \%$, factor three $9.54 \%$, factor four contributed $9.04 \%$ of the total variation, factor five $8.30 \%$ of the total variance of in the organization structure constructs. Component matrix results for organizational structure constructs were exposed in Table VII showing how each item of organizational structure loaded into a specific extracted component.

As exposed in Table VII, the rotated component matrix indicated evidence of construct validity from the simple structure. From research outcomes, the rotated component matrix had recognized 5 key factors. Component one among others was loaded with the statements that; learning organizational structure gives employees knowledge which enable them to own actions for better performance (0.746); learning structure enables participation in the innovation management for achievement of business goals efficiently (0.857) and team structures makes employees to own their job activities increasing effectiveness and productivity $(0.789)$. 
Items loaded each to a specific component meaning there was construct validity of the scale.

TABLE VII: ROTATED MATRIX FOR ORGANIZATIONAL STRUCTURE COMPONENTS

\begin{tabular}{|c|c|c|c|c|c|}
\hline Measures & 1 & 2 & 3 & 4 & 5 \\
\hline $\begin{array}{l}\text { Teamwork structure has given employees sense of ownership of team roles improving job efforts } \\
\text { and performance }\end{array}$ & 0.101 & 0.743 & 0.047 & 0.040 & 0.107 \\
\hline $\begin{array}{l}\text { Team structures makes employees to own their job activities increasing effectiveness and } \\
\text { productivity }\end{array}$ & 0.789 & 0.067 & 0.057 & 0.020 & 0.093 \\
\hline $\begin{array}{l}\text { Team structures give team members ability to learn new skills giving them ownership of team } \\
\text { roles for increased efficiency }\end{array}$ & 0.018 & 0.073 & 0.018 & 0.132 & 0.032 \\
\hline $\begin{array}{l}\text { Team structures makes employees to take ownership of their responsibilities to be self- } \\
\text { accountable for better outcomes }\end{array}$ & 0.125 & 0.148 & 0.727 & 0.307 & 0.073 \\
\hline $\begin{array}{l}\text { Team structures empower employees to build consensus and to gain ownership of decisions for } \\
\text { better productivity. }\end{array}$ & 0.340 & 0.158 & 0.038 & 0.266 & 0.752 \\
\hline $\begin{array}{l}\text { Learning organizational structure s are built around company values to instill ownership of goals } \\
\text { for more achievements }\end{array}$ & 0.047 & 0.209 & 0.377 & 0.000 & 0.756 \\
\hline $\begin{array}{l}\text { Learning organizational structure allows teams to gain collective ownership of goals, hence } \\
\text { improving profits }\end{array}$ & 0.254 & 0.043 & 0.060 & 0.086 & 0.069 \\
\hline $\begin{array}{l}\text { Learning organizational structure allows discussions about the company`s vision leading to } \\
\text { ownership for better performance }\end{array}$ & 0.151 & .324 & 0.268 & 0.199 & 0.140 \\
\hline $\begin{array}{l}\text { Learning structure enables participation in the innovation management for achievement of } \\
\text { business goals efficiently }\end{array}$ & 0.857 & 0.157 & 0.136 & 0.435 & 0.095 \\
\hline $\begin{array}{l}\text { Learning organizational structure gives employees knowledge which enable them to own actions } \\
\text { for better performance }\end{array}$ & 0.746 & 0.002 & 0.128 & 0.224 & 0.000 \\
\hline $\begin{array}{l}\text { Boundaryless organizational structures make self-managing teams instill ownership of team roles } \\
\text { to increase effectiveness }\end{array}$ & 0.049 & 0.048 & 0.148 & 0.220 & 0.760 \\
\hline $\begin{array}{l}\text { Boundaryless organizational structures promote employee ownership of decisions and this } \\
\text { improves efficiencies }\end{array}$ & 0.087 & 0.110 & 0.046 & 0.829 & 0.137 \\
\hline $\begin{array}{l}\text { Boundaryless organizational structure eliminates unnecessary bureaucratic o activities to achieve } \\
\text { goals effectively }\end{array}$ & 0.070 & 0.178 & 0.749 & 0.033 & 0.184 \\
\hline $\begin{array}{l}\text { Boundaryless organizational structure allows ad hoc cross-functional teams to eliminate or } \\
\text { combine some activities and take ownership to improve results }\end{array}$ & 0.151 & 0.136 & 0.632 & 0.129 & 0.080 \\
\hline $\begin{array}{l}\text { Boundaryless organizational structure gives employees new ways of solving problems boosting } \\
\text { morale and creating ownership of job activities for increased effectiveness }\end{array}$ & 079 & 767 & 0.055 & 0.132 & 0.050 \\
\hline
\end{tabular}

Extraction Method: Principal Component Analysis.

Rotation Method: Varimax with Kaiser Normalization.

Source: Primary Data, 2020ю

\section{Correlation Analysis}

The correlation between organizational structure`s constructs and organizations` performance of MTNOs in Kenya was determined using Pearson correlation and Table VIII shows correlation results. in the relationship with organizations' performance of MTNOs. The results agree with [8] who concluded that organization`s structure influenced financial performance of commercial state corporations in Kenya. However, the results disagreed with [9] who found organizational structure did not determine performance.

TABLE VIII: ORGANIZATIONAL STRUCTURE AND PERFORMANCE

\begin{tabular}{ccccc}
\multicolumn{5}{c}{ TABLE VIII: ORGANIZATIONAL STRUCTURE AND PERFORMANCE } \\
\hline $\begin{array}{c}\text { OP } \\
\text { Organization's performance }\end{array}$ & 1 & TOS & LOS & BOS \\
$\begin{array}{c}\text { Team } \\
\text { organizational structure } \\
\text { Learning }\end{array}$ & $.479 *$ & 1 & & \\
$\begin{array}{c}\text { organizational structure } \\
\text { Boundaryless organizational } \\
\text { structure }\end{array}$ & $.354^{*}$ & $.142^{*}$ & 1 & \\
$\quad .585^{*}$ & $.509^{*}$ & $.654^{*}$ & 1
\end{tabular}

* Correlation is significant at the 0.05 level (2-tailed).

Source: Researcher, 2020.

Key: OP- Organization`s performance.

TOS- Team Organizational Structure.

LOS- Learning Organizational Structure.

BOS- Boundaryless Organizational Structure.

As given in Table VIII, the correlations between all the measures of organizational structure and organizations' performance of MTNOs were positive and statistically significant at $\mathrm{P}<0.05)$. Team organizational structure, learning organizational structure and boundaryless organizational structure all correlated positively statistically and significantly with organizations` performance $(\mathrm{r}=0.479$, $\mathrm{P}<0.05),(\mathrm{r}=0.354, \mathrm{P}<0.05)$ and $(\mathrm{r}=0.585, \mathrm{P}<0.05)$ respectively. This implied that the dimensions of team organizational structure, learning organizational structure and boundaryless organizational structure all had significant role

\section{E. Regression Analysis}

The study's objective was to investigate influence of organizational structure (teamwork organizational structure, learning organization structure and boundary-less organizational structure) on performance (profit margins, and market share) of MTNOs in Kenya. Respondents were required to indicate how organizational structure had affected performance of their MTNOs by choosing from a range of five- point Likert scale responses (ranging from strongly agree to strongly disagree). For this purpose, the following null hypothesis was stated and tested: $H_{0}$ : Organizational structure does not positively influence performance of MTNOs in Kenya.

TABLE IX: ORgANiZATIONAL STRUCTURE AND PERFORMANCE MODEL

\begin{tabular}{|c|c|c|c|c|}
\hline \multicolumn{5}{|c|}{ SUMMARY } \\
\hline Model & $\mathrm{R}$ & $\mathrm{R}^{2}$ & Ad. $\mathrm{R}^{2}$ & SEE \\
\hline 1 & $0.405^{\mathrm{a}}$ & 0.164 & 0.160 & 1.15303 \\
\hline
\end{tabular}

a. Predictors: (Constant), Organizational Structure.

Source: Primary Data, 2020.

Key: SEE - Standard Error of the Estimate.

Ad.-Adjusted.

Goodness of fit model (Table IX) denoted that organizational structure had a constructive association with 
performance of MTNOs $(\mathrm{R}=0.405)$. Organizational structure had explanatory ability over performance of MTNOs since it is behind $16.4 \%$ variation in organizations' performance of MTNOs ( $\mathrm{R}$ squared $=0.164$ ) while $83.6 \%$ variation is accounted for by other factors which are not in this model. The ANOVA (Table $\mathrm{X}$ ) suggested that organizational structure influenced organizations' performance significantly where $\mathrm{F}=50.114(1,256) \mathrm{P}<0.05$. The ANOVA result are in Table X:

TABLE 1: ORgANIZATIONAL STRUCTURE AND PERFORMANCE ANOVA

\begin{tabular}{ccccccc}
\hline $\mathrm{M}$ & & SS & DF & MS & F & Sig \\
\hline 1 & Reg. & 66.601 & 1 & 66.601 & 50.114 & $.000^{\mathrm{a}}$ \\
& Res. & 340.349 & 25 & 1.329 & & \\
& Total & 406.950 & 25 & & & \\
\hline
\end{tabular}

a. Predictors: (Constant), Organizational Structure.

b. Dependent Variable: Organizations' performance.

Source: Primary Data, 2020.

Key: Reg. - Regression, Res - Residual, SS - Sum of Squares, MS - Mean Square, DF- Degrees of Freedom.

\section{F. Hypothesis Testing}

Hypothesis $\left(\mathrm{H}_{0}\right)$ was tested where the testing criterion was to reject $\mathrm{H}_{0}$ if $\mathrm{P}$-value was $<0.05$ and $\beta \neq 0$ otherwise fail to reject $\mathrm{H}_{0}$. The results of hypothesis testing are in Table XI.

TABLE XI: OS AND PERFORMANCE OF MTNOS COEFFICIENTS

\begin{tabular}{ccccccc}
\hline & & \multicolumn{2}{c}{ UC } & \multicolumn{3}{c}{ SC } \\
\cline { 3 - 7 } $\mathrm{M}$ & $\mathrm{B}$ & Std. Error & $\begin{array}{c}\text { Beta } \\
(\beta)\end{array}$ & $\mathrm{T}$ & Sig \\
\hline & $\mathrm{C}$ & 1.863 & 0.232 & & 8.030 & 0.000 \\
1 & $\mathrm{OS}$ & 0.432 & 0.061 & 0.405 & 7.081 & 0.000 \\
\hline
\end{tabular}

a. Dependent Variable: Performance of MTNOs.

Key: OS - Organizational Structure, M- Model, MTNOs - Mobile Telephone Network Operators, UC - Unstandardized Coefficients, SC Standardized Coefficients, $\mathrm{C}$ - Constant.

Source: Primary Data, 2020.

The standardized coefficients in Table XI divulged a statistically remarkable and positive influence of organizational structure on performance of MTNOs $(\beta=$ 0.405 , and $\mathrm{P}=0.000)$. Founded on the research outcome, $\beta \neq$ 0 and $\mathrm{P}<0.05$, the researcher thus, rejected $\mathrm{H}_{0}$ and stated that organizational structure influenced performance of MTNOs. The scores of organizations' performance of MTNOs were regressed on the scores of the three organizational structure measures and the relevant results presented in Tables XII.

TABLEXII: OS MEASURES AND PERFORMANCE COEFFICIENTS

\begin{tabular}{cccccc}
\hline \multirow{2}{*}{ M } & \multicolumn{2}{c}{ UC } & \multicolumn{2}{c}{ SC } & \multirow{2}{*}{ Sig } \\
\cline { 2 - 5 } & B & Std. Error & Beta & T & \\
\hline C & 0.599 & 0.284 & & 2.109 & 0.036 \\
TOS & 0.249 & 0.061 & 0.217 & 4.082 & 0.000 \\
LOS & 0.180 & 0.051 & 0.174 & 3.529 & 0.002 \\
BOS & 0.426 & 0.061 & 0.396 & 6.984 & 0.000 \\
\hline
\end{tabular}

a. Dependent Variable: Organizations' Performance.

Key: M - Model, OS - Organizational Structure, TOS - Teamwork Organizational Structure, LOS - Learning Organizational Structure, BOS Boundaryless Organizational Structure, UC - Unstandardized Coefficients, C - Constant, SC - Standardized Coefficients.

Source: Primary Data, 2020.

Table XII showed that organizational structure measures had an important contribution to the coefficient model of organizations' performance $(\mathrm{T}=2.109, \mathrm{P}<0.05)$. The model parameters in Table XII had the indication that when boundary-less organizational structure is used as a predictor, its contribution to the model is significantly higher than the other measures $(\mathrm{T}=6.984, \mathrm{P}<0.05)$. Additionally, the predictive strength of teamwork organizational structure contribution in the coefficient model was similarly significant ( $\mathrm{T}=4.082, \mathrm{P}<0.05)$.

On the other hand, when learning organizational structure was used as a predictor, its contribution to the model was significantly important $(\mathrm{T}=3.529, \mathrm{P}<0.05)$. The coefficients results show that all the measures of organizational structure had positive and significant influence on organizations' performance of MTNOs as follows: teamwork organizational structure had positively and significantly influenced organizations' performance of MTNOs $(\beta=0.217$ and Pvalue $=0.000)$, learning organization structure also positively affected organizations' performance of MTNOs $(\beta=0.174$, $\mathrm{P}$-value $=0.002$ ) and boundary-less organizational structure on the other hand had a positive effect on organizations' performance of MTNOs $(\beta=0.396, \mathrm{P}=0.000)$.

Based on Table XII, regression equation that can forecast degree of performance of MTNOs for a standard deviation rise in teamwork organizational structure, learning organization structure and boundary-less organizational structure can be expressed as:

$\mathrm{OP}=0.599+0.249(\mathrm{TOS})+0.180($ LOS $)+0.426(\mathrm{BOS})+\varepsilon$

where:

OP = Organizations' Performance of MTNOs;

$0.599=$ the $Y$ - intercept constant;

$0.249,0.180$, and $0.426=$ an estimate of the expected increase in organizations' performance of MTNOs corresponding to an increase in use of a standard deviation of teamwork organizational structure, learning organization structure and boundary-less organizational structure respectively;

TOS = Teamwork Organizational Structure;

LOS = Learning Organization Structure;

BOS = Boundary-less Organizational Structure;

$\varepsilon=$ Error Term.

\section{G. Summary of Study Findings}

Factor analysis for organizational structure results indicated that it had a KMO index greater than the conventional minimum probability value of 0.5 . The correlation analysis results showed a statistically constructive connection between all the measures of organizational structure and organizations' performance of MTNOs: Team organizational structure, learning organizational structure and boundaryless organizational structure all correlated positively statistically and significantly with organizations performance $(\mathrm{r}=0.479, \mathrm{P}<0.05),(\mathrm{r}=0.354, \mathrm{P}<0.05)$ and $(\mathrm{r}=0.585, \mathrm{P}<0.05)$, respectively. The study`s regression outcome gave a statistically significant positive influence of organizational structure on performance of MTNOs ( $\mathrm{P}<$ $0.05)$ with $\beta \neq 0$ hence $\mathrm{H}_{0}$ was rejected. Regression outputs showed that organizations' performance of MTNOs was correlated with organizational structure measures $(\mathrm{R}=0.405)$ and $16.4 \%$ of MTNOs performance was explained by organizational structure regression model $\left(R^{2}=0.164\right)$. 


\section{CONCLUSION}

The regression results exposed that the extent to which organizational structure influenced performance of MTNOs in Kenya was significant $(\mathrm{P}<0.05)$. The study therefore concluded that there was a statistically important effect of organizational structure on organizations' performance of MTNOs firms in Kenya. The objective of the study was confirmed that: the extent to which organizational structure influences organizations' performance of MTNOs was statistically significant and the null hypothesis which stated that "organizational structure does not positively influence performance of MTNOs in Kenya" was disapproved at ( $\beta=$ 0.405, and $\mathrm{P}=0.000)$. Regression analysis showed organizational structure had a constructive association with performance of MTNOs $(\mathrm{R}=0.405, \mathrm{R}$ squared $=0.164$ and the model was significant at $\mathrm{F}=50.114(1,256) \mathrm{P}<0.05$.

\section{A. Recommendations}

This study recommended that MTNOs in Kenya need to consider putting in place agile organizational structures such as teamwork organizational structure, learning organization structure and boundary-less organizational structure at departmental or unit level to enhance MTNOs` performance.

\section{B. Recommendations for Further research}

The study was cross-sectional research carried out at one point in time. This study suggests further study on the same area which will employ longitudinal research design. The study also recommends a similar study but focusing on a different industry.

\section{REFERENCES}

[1] Burton, R., Obel, B., \& Hakonsson, D. (2015). Organizational Design: A Step-by-Step Approach (3rd ed.). London: Cambridge University Press.

[2] Meyer, D. N. (2017). Principle-based Organizational Structure: a handbook to help you engineer entrepreneurial thinking and teamwork into organizations of any size (1st ed.). New Delhi: National Disastor Management Authority Publishing.

[3] Osawa, J. (2018). Huawei, Apple, Samsung supremacy. Wall street journal, 10-12.

[4] Kesler, G., \& Kates, A. (2010). Leading Organization Design: How to Make Organization Design Decisions to Drive the Results You Want (1st ed.). San Francisco Bay: Jossey-Bass.

[5] Galbraith, J. R. (2014). Designing Organizations: Strategy, Structure, and Process at the Business Unit and Enterprise Levels (3rd ed.). San Francisco Bay: Jossey-Bass.

[6] Funminiyi, A. K. (2018). Impact of Organisational Structure on Employee Engagement: Evidence from North Central Nigeria. International Journal of Advanced Engineering, Management and Science (IJAEMS) 4 (8) 579-789.

[7] Morrison, R. (2015). Data-driven Organization Design: Sustaining the Competitive Edge Through Organizational Analytics (1st ed.). London: Kogan Page.

[8] Njiru, J. N. (2014). The effect of organizational structure on financial performance of commercial state corprations in Kenya. Retrieved June 17, 2018, from erepository.uonbi.ac.ke/.../Njiru_The\%20effect.

[9] Omondi, J. S. (2017). The Relationship between Organization Structure and Performance in Commercial Banks in Kenya: The Mediating Role of Innovation. International Journal of Academic Research in Business and Social Sciences, 7(4), 633-663.

[10] Ogusi, C. D., \& Ogbaeze, E. K. (2018). Structure and Organizational Performance in the. European Journal of Social Sciences, 56(1), 37-48.

[11] Hickson, J. D. (1971). Strategic contingencies theory. Administrative science quarterly, 16, 216-229.

[12] Selto, F. H., Renner, C. J., \& Young, S. M. (1995). Assessing the organizational fit of a just-in-time manufacturing system: Testing selection, interaction and systems models of contingency theory. Accounting, organizations, society, 20(8), 665-684.

[13] Janne, K. (2017). Mapping the possibilities of contingency theory in organization. Retrieved June 21, 2018, from https://jyx.jyu.fi/ bitstream/handle/123456789.

[14] Donaldson, L. (2001). The Contingency Theory of Organizations. Thousand Oaks: Sage Publications.

[15] Adom, D., Hussein, E. K., \& Agyem, J. A. (2018). Theoretical and Conceptual Framework: Mandatory Ingredients of a Quality Research; International Journal Of Scientific Research, 7 (1), 438-441.

[16] Wilson, J. (2010). "Essentials of Business Research: A Guide to Doing Your Research Project". New York: SAGE Publications.

[17] Krejcie, R. V., \& Morgan, D. W. (1970). Determining Sample Size for Research Activities. Educational and Psychological Measurement, 30, 607-610.

[18] Sukhatme, P. V., Sukhatme, B. V., Sukhatme, S., \& Asok, C. (1984). Sampling Theory of Surveys with Applications. Ames, Iowa: Iowa State University Press.

[19] Sekaran, U., \& Bougie, R. (2016). Research Methods For Business: A Skill Building Approach. New York : John Wiley \& Sons.

[20] Fowler Jr, F. (2013). Survey research methods (applied social research methods (5th ed.). New York: Sage publishers.

[21] Hair, J. F., Black, B., Babin, B., \& Anderson, R. E. (2016). Multivariate Data Analysis (7th ed.). hUpper Saddle River, NJ: Pearson Education.

[22] Bruin, J. (2016). Introduction to SAS. UCLA: Statistical Consulting Group. From: https://stats.idre.ucla.edu/sas/modules/ (accessed August $22,2016)$. 